STAINU Purworejo: Jurnal As Sibyan Jurnal Kajian Kritis Pendidikan Islam

\title{
IMPLEMENTASI TOTALQUALITYMANGEMENT (TQM) DI MADRASAH IBTIDAIYAH DARUL HUDA YOGYAKARTA
}

\author{
Hafidz \\ STIT Madani Yogyakarta, Indonesia \\ dr.hafidz.2020@gmail.com \\ Husna Nashihin \\ Mahasiswa S3 PAI Unwahas Semarang, Indonesia \\ aufahusna.lecture2017@gmail.com
}

\begin{abstract}
Abstrak
Penelitian ini termasuk peneltiian lapangan dengan mengambil MI Darul Huda sebagai sumber datanya. Penelitian ini menggunakan analisis data kualitatif deskriptif. Ada lima latar belakang penilitian ini, yaitu, pertama, globalisasi telah mengharuskan peningkatan kualitas mutu Pendidikan di Indonesia. Kedua, keberhasilan dalam persaingan dunia Pendidikan saat ini sangat tergantung pada kualitas mutu Pendidikan yang dimiliki. Ketiga, diperlukannya sebuah metode peningkatan mutu Pendidikan secara terpadu dan berkelanjutan. Keempat, Total Quality Mangement merupakan salah satu metode yang efektif diterapkan dalam dunia Pendidikan. Kelima, MI Darul Huda dapat menjadi contoh penerapan Total Quality Mangement yang baik.Hasil penelitian ini menunjukkan bahwa Total Quality Mangement di MI Darul Huda diterapkan pada lima aspek, yaitu Pelayanan Manajemen terhadap Pelanggan Internal, Pelayanan Manajemen terhadap Peserta Didik, Pelayanan Manajemen terhadap Orangtua, Pelayanan Manajemen terhadap Madrasah sebagai Sistem, dan Pelayanan Manajemen terhadap Madrasah Lanjutan.
\end{abstract}

Kata Kunci : Implementasi; Manajemen Pendidikan; Total Quality Mangement

\begin{abstract}
This research includes field research by taking MI Darul Huda as the data source. This research uses descriptive qualitative data analysis. There are five backgrounds for this research, namely, first, globalization has required improving the quality of education in Indonesia. Second, success in today's competition in the world of education is very much dependent on the quality of education that is owned. Third, the need for a method of improving the quality of education in an integrated and sustainable manner. Fourth, Total Quality Management is one method that is effectively applied in the world of education. Fifth, MI Darul Huda can be an example of a good application of Total Quality
\end{abstract}


Management. The results of this study indicate that Total Quality Management at MI Darul Huda is applied to five aspects, namely Management Services for Internal Customers, Management Services for Students, Management Services for Parents, Management Services for Madrasahs as Systems, and Management Services for Advanced Madrasahs.

Keywords : Implementation; Education Management; Total Quality Mangement

\section{A. Pendahuluan}

Globalisasi mengharuskan Pendidikan di Indonesia pada umumnya untuk senantiasa meningkatkan kualitas mutu pendidikannya secara continue, baik dari kualitas input, proses, maupun outputnya. Dunia Pendidikan jika tidak mampu menyesuaikan diri dengan kemajuan yang ada, maka tidak akan mampu memenuhi kubutuhan masyarakat di bidang sumber daya manusia.Hal itu perlu dilakukan karena satu dekade terakhir pasar dan persaingan pendidikan menjadi lebih luas, terlebih setelah terbitnya UU No. 20 Tahun 2003 pasal 65 ayat 1 yang menyebutkan bahwa, "Pendidikan asing yang terakreditasi atau yang diakui di negaranya dapat menyelenggarakan pendidikan di wilayah Negara Kesatuan Republik Indonesia sesuai dengan peraturan perundang-undangan yang berlaku".

Upaya peningkatan mutu Pendidikan menjadi sebuah keharusan mengingat persaingan kualitas mutu Pendidikan di Indonesia yang semakin meningkat, apalagi semakin banyaknya sekolah-sekolah dari luar negeri yang masuk ke Indonesia dengan segala diferensiasi kurikulumnya. Hal ini rupanya semakin membuat dunia Pendidikan di Indonesia semakin terdesak, apalagi bagi sekolah yang belum memiliki kesiapan untuk bersaing. Dorongan liberalisasi pendidikan sepertinya memang sulit untuk dihindari, sebab kompetensi akan semakin kuat dan dorongan pasar juga akan berkembang seiring dengan ekspektasi tinggi terhadap lulusan yang siap memasuki bursa kerja, meskipun karakteristik lembaga pendidikan sebagai organisasi nirlaba jelas tetap perlu dijunjung tinggi. ${ }^{1}$

Guna meningkatkan kualitas mutu Pendidikan di Indonesia, maka dibutuhkan human capital yang mampu mendongkrak kualitas mutu Pendidikan yang sudah ada. Kualitas human capital menjadi

${ }^{1}$ Uhar Suharsaputra, Manajemen Pendidikan Perguruan Tinggi (Bandung: Refika Aditama, 2015), hlm.3. 
penentu keberhasilan persaingan global (termasuk keunggulan pendidikan), dan untuk menghasilkannya diperlukan metode yang terukur dan terencana melalui pendidikan yang bermutu.

Pendidikan yang bermutu salah satu tolak ukurnya adalah mampu bersinergi dengan segala kebijakan sistem nasional maupun daerah, baik pada dataran konsep maupun teknis pelaksanaan kebijakan.Eksistensi sebuah Lembaga Pendidikan dilihat dari peningkatan mutu yang dilakukan dalam menghadapi persaingan yang ada dengan indicator pelanggan yang terus berubah, kompleksitas produk, dan tingkat harapan pelanggan yang meningkat, bahkan akan terus berkembang manakala pelanggan loyal.

Pendidikan dapat dikatakan bermutu jika memiliki kualitas input proses dan hasil yang bermutu, baik dari peserta didik, pendidik, maupun tenaga kependidikannya. Sistem ini biasanya disebut quality learning process. Terdapat banyak metode peningkatan mutu Pendidikan yang saat ini sudah dilaksanakan, namun salah satu metode peningkatan quality learning process yang banyak digunakan adalah Total Quality Management (TQM).

TQM menekankan pada keberlanjutan aspek mutu Pendidikan yang diukur berdasarkan tercapainya kebutuhan dan kepuasan pengguna Pendidikan. Salah satu lembaga pendidikan yang menerapkan sistem ini adalah MI Darul Huda. Madrasah ini semenjak menerapkan TQM dalam membangun Lembaga pendidikannya, terus mengalami peningkatan peserta didik, baik secara kualitas maupun kuantitas.

MI Darul Hudamerupakan madrasah dasar yang berkarakter Islam dan unggul dalam pengelolaan sistem pendidikannya. Pelayanan yang diberikan oleh pihak madrasah mampu memikat perhatian pelanggan pendidikan, baik pelanggan internal maupun ekternal. Meskipun MI Darul Hudaberstatus sebagaimadrasahswasta,namunMI Darul

Hudamerupakansalahsatumadrasah

favoritdiYogyakarta,sehinggaMI

Darul

Hudabanyakdiminatiolehmasyarakat dan oleh para lulusan-lulusan terbaik universitas untuk menjadi tenaga pengajar ataupun tenaga kepegawaian disana.

MI Darul Hudadengan segala totalitasnya terus berbenah dan memberikan kesempatan untuk memotivasi dan memenuhi harapan pelanggan madrasah (pendidik, pesertadidik, pegawai, orangtua, masyarakat danlembaga pendidikan lanjutan). Lembaga pendidikan 
dasar yang berbudaya mutu tersebut memberikan layanan jasa melebihi harapan pelanggan. Hal tersebut dapatdilihatdaribudayamadrasahyangkondusif,prosesbelajarmengajar yang efektif, sarana prasarana yang memadai, kurikulum yang jelas dan terarah, pendidik dan tenaga kependidikan yang kompeten.

Seiring dengan pertumbuhan dunia global, MI Darul Hudaterus melakukan pengembangan diri dan perbaikan secara kontinu yang terkonsep dalampenerapanTotalQualityManagement(TQM). MI Darul Hudaunggul dalam semua kategori, baik kategori pembelajaran, manajemen berbasis madrasah, kegiatan ekstrakurikuler, maupun perpustakaan. Dari rekam jejak seperti tergambardi atas, penelitian ini berusaha menelusuri bagaimana proses implementasi TQM,faktorfaktorapasajayangmenjadipenghambat;danfaktor-faktorapa yang paling mendukung terhadap berjalannya TQM di MI Darul Huda.

\section{B. Pembahasan}

Total Quality Management di MI Darul Huda merupakan representasi dari system penjaminan mutu pendidikan di Madrasah tersebut. MI DarulHuda melalui metode tersebut terus berbenah secara total di berbagai aspek pendidikan, sehingga mampu menjadi Madrasah yang unggul di kancah lokal maupun nasional.

Langkah pertama, yang dilakukan MI Darulhuda dalam mengimplementasikan total quality management yaitu merumuskan visi dan misi madrasah. Selanjutnya, visi dan misi Madrasah tersebut dijabarkan dalam rencana strategis madrasah dengan mengacu pada kebijakan mutu. Ada empat poin kebijakan mutu yang diterapkan di MI DarulHuda, yaitu; 1) meluluskan peserta didik siswi berakhlak mulia dan berprestasi akademis optimal; 2) mewujudkan pendidikan yang berorientasi global dan kompetitif di tingkat dunia dengan berdasarkan niali-nilai Islam dan kebangsaan; 3) memberikan pelayanan prima dengan mengutamakan kepuasan stake holder; 4) komitmen ini diwujudkan dengan cara: a) melakukan standarisasi SDM, sistem, dan pelayanan; b) memperluas jaringan dan kerja sama dengan lembaga lain; c) memenuhi persyaratan-persyaratan yang dibutuhkan. Komitmen tersebut dilakukan dengan ikhlas dan sungguhsungguh.

Berdasarkan kebijakan mutu Madrasah yang telah disusun, MI

Darul Huda menyusun perencanaan serta pelaksanaan strategi penjaminan mutu Madrasah. Strategi penjaminan mutu di MI Darul 
Huda lebih menekankan pada mutu pelayanan pendidikan. Mutu pelayanan pendidikan di MI DarulHuda meliputi; 1)pelayanan manajemen terhadap pendidik dan karyawan;2) pelayanan manajemen terhadap peserta didik; 3) pelayanan manajemen terhadap orangtua; 4) pelayanan manajemen terhadap pendidikan lanjutan; 5) pelayanan manajemen terhadap madrasah sebagai sistem; dan 6) pelayanan pendidikterhadap peserta didik.

Filosofi management yang digunakan dalam TQM, adalah perbaikan berkelanjutan yang mampu memenuhi kebutuhan, keinginan, dan harapan para pengguna baik saat ini maupun masa yang akan datang. Dalam implementasinya, TQM mengharuskan adanya komitmen bersama semua personil madrasah dalam meningkatkan mutu pendidikan di semua aspek. Secara substansial, TQM tidak mengacu pada usaha mengatasi persaingan mutu lembaga lain, namun implementasi TQM lebih berfokus pada melaksanakan agenda mutu pendidikan yang ditetapkan oleh pengguna. Dengan kata lain, TQM merupakan kewajiban semua personil, tidak hanya kewajiban para pimpinan belaka. ${ }^{2}$

Jabaran filosofi TQM di MI DarulHuda dilaksanakan melalui dua acara, yaitu filosofi perbaikan berkelanjutan dan mendeskripsikan unit unit perbaikan mutu yang ada. Langkah ini dilakukan melalui kegiatan Brainstorming dan analisis lapangan. Upaya peningkatan mutu di MI Darulhuda juga mengacu pada standar mutu pendidikan yang ditetapkan oleh pemerintah. ${ }^{3}$

Secara teoritis, tenner dan detoro memaparkan ada tiga prinsip penjaminan mutu yang dilaksanakan melalui TQM. Prinsip prinsip ini juga selaras dengan prinsip penjaminan mutu TQM yang diberlakukan di Mi DarulHuda, yaitu berfokus pada pelanggan, peningkatan mutu berkelanjutan, dan keterlibatan semua personil. Melalui ketiga prinsip tersebut, dalam implementasinya TQM di MI DarulHuda selalu menggali keinginan dari para peserta didik, wali murid dan pengguna lulusan. Selain itu, MI DarulHuda juga menerapkan Total Involment dengan melibatkan semua personil seperti kepala madrasah, pendidik, tenaga kependidikan, peserta didik dan wali murid secara total dalam pelaksanaan pendidikan.

${ }^{2}$ Edward Sallis, Total Quality Mangement in Education. (Yogyakarta: IRCiSoD, 2015), hlm. 62.

${ }^{3}$ Marno dan Triyo Supriyatno, Manajemen dan Kepemimpinan Islam (Bandung: Refika Aditama, 2008),hlm.112. 
Dalam implementasinya, TQM menggunakan kepuasan pelanggan sebagai salah satu indikator keberhasilan. Tingkat kepuasan pelanggan sangat bergantung pada tingkat pelayanan mutu pendidikan yang diberikan. Samani memaparkan bahwa ada hubungan antara kepuasan pelanggan dengan kualitas pelayanan $^{4}$ yang dapat digambarkan melalui bagan sebagai berikut :

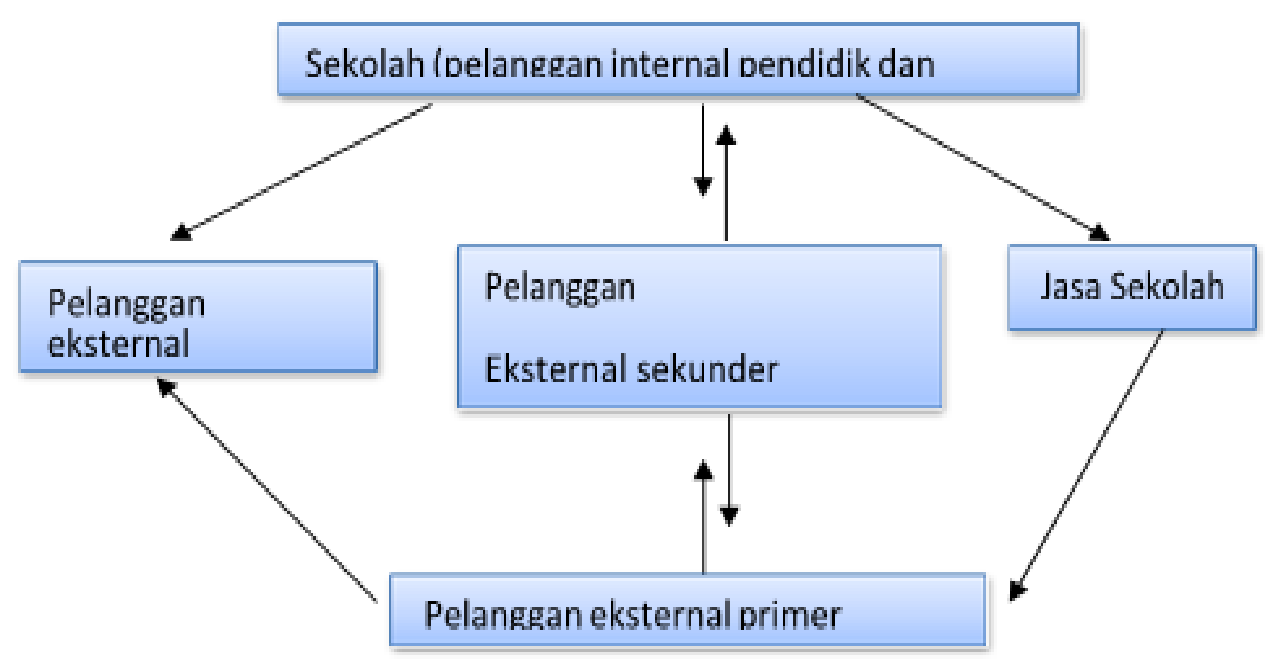

Ada empat indikator yang dapat digunakan untuk mengukur tingkat keberhasilan mutu madrasah, termasuk jug mutu pendidikan di MI Darul Huda, yaitu, 1) peserta didik puas dengan layanan madrasah, antara lain puas dengan pelajaran yang diterima, puas dengan perlakuan oleh pendidik maupun pimpinan; 2) orangtua peserta didik puas dengan layanan terhadap anaknya maupun layanan kepada orangtua; 3) pihak pemakai/penerima lulusan (perpendidikan tinggi, industri, masyarakat) puas karena menerima lulusan dengan kualitas yang sesuai harapan; 4) pendidik dan karyawan puas dengan layanan madrasah terkait pembagian kerja, budaya madrasah, hubungan kerja, dan motivasi.

Berry dan Parasuraman menuturkan bahwa ada lima faktor ${ }^{5}$ penentu mutu pendidikan yang harus diwujudkan sebuah lembaga pendidikan, termasuk juga MI Darul Huda.Pertama, keandalan (reliability), yaitu kemampuan sebuah lembaga pendidikan untuk memberikan jasa sesuai dengan perencanaan yang telah

${ }^{4}$ Muchlas Samani, dkk.,Manajemen Sekolah (Yogyakarta: Adicita Karya Nusa, 2009), hlm. 193.

${ }^{5}$ Parasuraman A, Leonard Berry, dan Valarie A. Zeithaml, "The Nature and Determinant of Custumer Expectations of Service," Journal of the Academy of Marketing Science 1 no. 21 (April, 1993): hlm.1-12. 
ditetapkan.Kedua, daya tanggap (responsiveness), yaitu kemampuan sebuah lembaga pendidikan dalam memberikan respon secara cepat dan tepat sesuai dengan perencanaan yang telah ditetapkan. Ketiga, kepastian (assurance), yaitu kemampuan sebuah lembaga pendidikan untuk dapat memberikan pelayanan yang meyakinkan kepada para pengguna jasa pendidikan yang meliputi peserta didik, wali murid, dan pengguna lulusan. Keempat, empati (emphaty), yaitu kemampuan lembaga pendidikan untuk dapat memberikan jasa sesuai dengan perencanaan yang telah ditetapkan secara berkualitas. Kelima, berwujud (tangible) ${ }^{6}$, yaitu kemampuan lembaga pendidikan untuk bisa menunjukan penampilan secara fisik yang meyakinkan, seperti bangunan, dan sarana pra sarana fisik lainnya.

Siklus dalam scientific management menejaskan bahwa sebuah kegiatan harus dimulai dengan tahap plan atau perencanaan, selanjutnya diikuti dengan tahapan $d o$ atau mengerjakan perencanaan yang telah disusun. Pada tahap pelaksanaan, didalamnya berisikan modifikasi-modifikasi yang diperlukan dengan mengacu pada evaluasi yang dilakukan atas pelaksanaan yang ada. Deming ${ }^{7}$ dalam teroinya memaparkan bahwa perbaikan-perbaikan yang dilakukan dalam siklus scientific management tidak ada ahirnya, sehingga harus dilakukan secara continue sebagaimana temuan yang didapatkan di lapangan.Perbaikan dilakukan dengan mengacu pada perencanaan yang telah disusun, sehingga evaluasi yang dilakukan memiliki indicator-indikator sebagaimana yang tertuang dalam perencanaan kegiatan. Berikut siklus scientific management menurut Deming;

${ }^{6}$ Zeithaml dan Bitner, Service Marketing (New Jersey: Graw Hill, 2000), hlm.20.

${ }^{7}$ Darmadji, "Implementasi Total Quality Management sebagai Upaya Peningkatan Mutu Pendidikan di MAN Model Yogyakarta," El-Tarbawy Jurnal Pendidikan Islam 1 No. 2 November, 2008, hlm.186. 


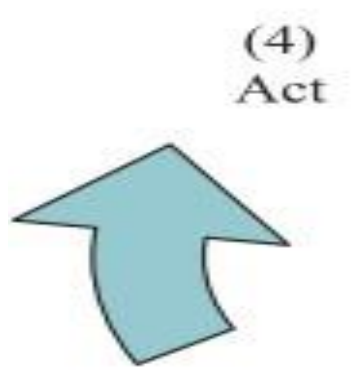

(3)
Study

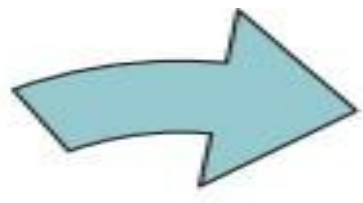

\section{(1)}

Plan

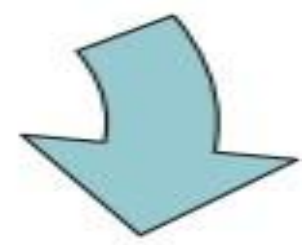

(2)

Do

Dalam melakukan perbaikan mutu pendidikan, MI Darul Huda menggunakan pertimbangan berupa isu-isu strategis dalam mutu pendidikan sebagai berikut; 1) misi dan visi (apa tujuan, visi, misi, dan nilai nilai suatu lembaga pendidikan); 2) harapan dan kebutuhan para pengguna terhadap lulusan pendidikan, sehingga kriteria lulusan yang dihasilkan dapat sesuai dengan yang dikehendaki oleh pengguna lulusan. 3) analisis kelemahan, kekuatan, peluang serta ancaman yang melingkupi lembaga pendidikan, sehingga dalam menyusun perencanaan dapat mempertimbangkan aspek-aspek tersebut secara matang. 4) standar mutu yang digunakan, sehingga indicator keberhasilan mutu pendidikan yang diinginkan jelas sesuai dengan kebutuhan yang diinginkan. 5) investasi sumber daya manusia yang dibutuhkan, sehingga semua perencanaan dapat dilaksanakan oleh sumber daya manusia yang berkompeten. 6) evaluasi proses yang berkelanjutan, sehingga ada perbaikan berkala yang dilakukan dalam proses pelaksanaan kegiatan.

MI Darul Huda dalam melaksanakan peningkatan mutu pendidikan melaksanakan langkah-langkah penting sebagai berikut;1) kepemimpinan dan komitmen mutu pendidikan; 2) kepuasan pengguna; 3) adanya fasilitator mutu pendidikan; 4) membentuk kelompok pengendali mutu pendidikan; 5) menunjuk koordinator mutu pendidikan; 5) mengadakan seminar manajemen mutu pendidikan;6)menganalisissituasi mutu pendidikan yang ada; 7) merujuk pada mutu pendidikan yang berjalan di tempat lain;8) 
memfungsikan konsultan ekternal; 9) mengadakan pelatihan peningkatan mutu pendidikan; 10) sosialisasi kebijakan mutu pendidikan; 11) mempertimbangkan alokasi biaya peingkatan mutu pendidikan; 12) menerapkan sistem peningkatan mutu pendidikan yag efektif dan efisien; 13) mengevaluasi semua program peningkatan mutu secara berkelanjutan. ${ }^{8}$

Berdasarkan hasil evaluasi, maka ada empat faktor penghambat pelaksanaan peningkatan mutu pendidikan di MI Darul Huda, yaitu; 1) paradigma kemimpinan tentang peningkatan mutu pendidikan yang belum menyeluruh pada semua SDM; 2) motivasi yang belum sama dari setiap SDM; 3) setidaktepatan delegasi kepada pelaksana program 4) keterbatasan akses biaya peningkatan mutu pendidikan. ${ }^{9}$

Ada enam faktor pendukung tercapainya peningkatan mutu pendidikan. Hal ini sesuai dengan memaparan Tenner dan Detoro yang juga mengemukakan ada enam faktor pendukung tercapainya peningkatan mutu pendidikan, yaitu; 1) Kepemimpinan, dalam TQM kepala madrasah berperan sebagai penasehat, pembimbing dan pemimpin tidak boleh terabaikan. (2) Pendidikan dan pelatihan, memberikan berbagai macam pendidikan dan pelatihan bagi pendidik dan karyawan untuk peningkatan profesionalitasnya (3) Struktur pendukung, adanya struktur organisasi yang jelas(4)Komunikasi,semuapegawaiharusmenerimainformasikualitasya ng jelas agar mereka sungguh sungguh melaksanakan program peningkatan kualitas (5) penghargaan, penghargaan perlu diberikan kepada tim maupun individu yang sukses dalam mengaplikasikan proses peningkatan kualitas. Hal ini dapat memacu mereka untuk lebih terdorong lagi mencapai kesuksesan (6) Pengukuran, ukuran yang digunakan adalah kepuasan pelanggan internal dan eksternal. ${ }^{10}$

Mutu pendidikan merupakan hasil akumulatif dari proses input, output dan outcome. Proses pendidikan yang dilaksanakan di MI Darul Huda menggunaan prinsip PAIKEM, yaitu pembelajaran aktif, inovatif, kreatif, dan menyenangkan. Output dinyatakan bermutu jika hasil belajar akademik dan nonakademik peserta didik tinggi. Outcome

\footnotetext{
${ }^{8}$ Sallis, Total Quality..., hlm.245.

${ }^{9}$ Sallis, Total Quality..., hlm.93.

${ }^{10}$ Tenner dan Detoro, Total Quality Management Three Steps to Continous Improvement,(New York: Addison Weley Publishing Company, 1992), hlm.32
} 
dinyatakan bermutu jika lulusan mampu melanjutkan kejenjangpendidikantinggiyangberkualitas,lulusancepatterserapdidunia kerja, gaji wajar, semua pihak mengakui kehebatan lulusan, dan merasa puas. ${ }^{11}$

KarakteristikTQMbiasanyamencakup:1)perubahankultur,lemba ga pendidikan menyediakan lingkungan yang cocok untuk para pendidik dan staf seperti alat alat keterampilan, sistem dan prosedur sederhana yang membantu pekerjaan mereka, penghargaan dan motivasi yang dapat meningkatkan kepercayaan diri serta memberdayakan setiap individu di dalamnya; 2) organisasi terbalik, yaitu kepemimpinan dalam TQM yang berlangsung dari atas ke bawah (top-down). Di sini pelanggan diposisikan di atas, membawahi perusahaan (mulai dari pimpinan hingga karyawan), melambangkan bahwa pelanggan yang diutamakan dan harus mendapat pelayanan prima, dalam kultur TQM peran manajemen senior danmenengah adalah memberi dukungan dan wewenang kepada para staf dan pelajar, bukan mengontrol mereka; 3) menjaga hubungan dengan pelanggan, baik pelanggan internal dan eksternal dengan berobsesi pada mutu melalui pelayananterbaik. ${ }^{12}$

\section{Pelayanan Manajemen terhadap Personil di MI Darul Huda}

Pelayanan manajemen mutu pendidikan di MI Darul Huda yang diberikan kepada pendidik dan karyawan dilaksanakan melalui; 1) penerapan sistem kerja pendidik dan tenaga kependidikan untuk bekerja sesuai dengan job description masing-masing. 2) penerapan sistem komunikasi yang kekeluargaan melalui kegiatan home visit antara pendidikan dan tenaga kependidikan dalam rapat bulanan bergantian tempatnya. 3) meningkatkan motivasi kerja pendidik dan tenaga kependidikan melalui kegiatan kajian keagamaan. 4) mengadakan kegiatan pelatihan dan workshop bagi pendidik dan tenaga kependidikan. 5) pemberlakuan reward dan punishment bagi pendidik dan tenaga kependidikan. 6) memberikan jaminan kesehatan kepada pendidik dan tenaga kependidikan beserta dengan keluarganya.

\footnotetext{
${ }^{11}$ Asmuni, “KonsepMutudanTotalQualityManagementdalamDuniaPendidikan," Ta'dibXVIII no.1 (Juni, 2013): 24.

${ }^{12}$ Sallis, Total Quality..., hlm.69.
} 
Ada dua macam bentuk kepuasan personil di MI Darul Huda terhadap pelayanan manajemen mutu pendidikan yang diterapkan, antara lain; 1) terpenuhinya kebutuhan spiritual pendidik dan tenaga kependidikan. 2) terpenuhinya kebutuhan materiil pendidik dan tenaga kependidikan berupa reward yang diberikan atas prestasi kerja pendidik dan tenaga kependidikan.

\section{Pelayanan Manajemen terhadapPeserta didik}

Manajemen mutu pendidikan yang terkait dengan pelayanan kepada peserta didik di MI Darul Huda dilakukan melalui lima hal, yaitu; 1) menyediakan sarana dan pra sarana yang memadai bagi peserta didik seperti UKS, Perpustakaan, Kantin, Tempat Olahraga, dan lain sebagaianya. 2) menerapkan kurikulum yang integratif, sehingga semua aktivitas baik akademik maupun non akademik di MI Darul Huda dilaksanakan secara sistemik dan terpadu. 3) membentuk situasi sosial di madrasah yang nyaman dan kondusif, sehingga desain lingkungan belajar di MI Darul Huda mampu mendukung tercapainya tujuan pendidikan di MI Darul Huda. 4) adanya reward dan punishment yang seimbang di MI Darul Huda.

Adanya integrasi yang baik dalam pemberian kurikulum, sarana prasarana, reward dan punishment, lingkungan madrasah dan program pendampingan yang continue di MI Darul Huda menjadikan TQM di madrasah ini dapat berlangsung secara maksimal. Totalitas semua personil sekolah, baik pendidik, tenaga kependidikan, maupun peserta didik menjadikan implementasi TQM semakin maksimal. Tercapaianya manajemen muutu pendidikan yang maksimal ini selanjutnya mampu menghantarkan MI Darul Huda menjadi madrasah yang berprestasi abik akademik maupun non akademik.

\section{Pelayanan Manajemen terhadapWali Murid}

Upaya peningkatan manajemen mutu pendidikan kepada wali murid di MI Darul Huda dilaksanakan dengan lima hal yaitu; 1) mengadakan buku penghubung, sehingga semua aspirasi dan kemajuan pendidikan para peserta didik dapat dimonitoring bersama antara pendidik dengan orang tua. 2) mengadakan home visit ke rumah-rumah para peserta didik secara bergilir. 3) mengadakan seminar mengenai parenting. 4) memaksimalkan komunikasi antara pendidik dan orang tua secara daring seperti aplikasi WA, Facebook dan lain sebagainya. 


\section{Pelayanan Manajemen terhadap Madrasah sebagaiSistem}

Pelayanan manajemen terhadap madrasah sebagai sistem dalam implementasitotalqualitymanajementMI Darul Hudaberdasarkanpada; 1)perencanaan strategis mutu. Rencana strategis mutu tidak terlepas dari visi, misi, nilai-nilai, tujuan madrasah, program dan target yang harus dicapai; 2) biaya mutu. Pembiayaan MI Darul Hudabersumber dari orangtua dan pengembangan usaha yang dilaksanakan oleh yayasan. Segala keperluan madrasah ditopang oleh yayasan dari hasil pengembangan usaha dan orang tua peserta didik tanpa menerima uang BOS maupun BOPDA; 3) pengawasan dan evaluasi proses pendidikan, yaitu pengawasan dan evaluasi jangka pendek terdiri dari pengawasan dan evaluasi harian serta mingguan. Pengawasan dan evaluasi jangka panjang dilakukan dalam bentuk supervisi, Selain supervisi yang dilakukan terhadap pendidik, MI Darul Hudajuga menyupervisi wali kelas sekali dalam setahun dan menyupervisi koordinator jenjang yang dilakukan setahun sekali.

\section{Pelayanan Manajemen terhadap MadrasahLanjutan}

Budaya madrasah yang baik seperti disiplin, internalisasi nilainilai keislaman serta penguasaan materi ajar oleh peserta didik adalah bentuk pelayanan madrasah terhadap pendidikan lanjutan. Dengan internalisasi karakter Islam dan penguasaan pengetahuan yang tertanam pada diri peserta didik, sehingga peserta didik dapat berakhlak mulia dan berprestasi akademik merupakan nilai plus bagi pendidikan lanjutan. Peserta didik yang terbiasa disiplin waktu, maka ia akan mudah diatur. Peserta didik yang cerdas akan memberi keutungan tersendiri pada lembaga lanjutan, sehingga ia tidak bersusah payah dalam membentuk karakter peserta didik dan dapat dengan mudah meningkatkan karakter serta mengembangkan tingkat pengetahuan peserta didik.

Pelayanan pendidik MI Darul Hudaterhadap peserta didik dalam kegiatan belajar mengajar sebagai berikut: 1) perencaan pembelajaran. Adapun yang dipersiapkan pendidik dalam perencanaan pembelajaran adalah metode pembelajaran, media pembelajaran, bahan ajar, reward dan punishment, bentuk evaluasi dan rubrik nilai serta remidi; 2) media pembelajaran. Media yang digunakan sesuai dengan mata pelajaran dan kebutuhan peserta didik seperti video pembelajaran; 3) metode pembelajaran. Kegiatan belajar mengajar di MI Darul Hudadengan pendekatan pembelajaran kontekstual, 
scientific dan student center; 4) bahan ajar. Berdasarkan kurikulum yang digunakan, yaitu kurikulum Dinas Pendidikan, kurikulum khas Al-Hikmah dan kurikulum Cambridge; 5) reward dan punishment. Reward yang diberikan dalam proses belajar mengajar di kelas pada umumnya adalah berupa pujian dan kesempatan tampil di depan para pendidik jajaran manajemen; 6) evaluasi pembelajaran. Evaluasi pembelajaran MI Darul Hudadilaksanakan melalui UTS, UAS dan ujian harianserta;7)remidi.ProgramremidiMI Darul Hudaterdiridariremidi pengajaran untuk individu, kelompok dan tutor sebaya dan remidi terapi psikologis untuk menumbuhkan motivasi, memperbaiki prilaku sosial, dan mengatasipenyimpangan.

\section{Kesimpulan}

Kesuksesan peningkatan mutu Pendidikan di MI Darul Huda tidak terlepas dari konsisten penerapan total quality management yang berfokus pada kualitas input, proses, dan output pendidikannya. Keberhasilan ini juga tidak terlepas dari keterlibatan seluruh stake holder MI Darul Huda.

MI Darul Huda dalam menerapkan total quality management mengacu pada prinsip keandalan, daya tanggap, empati, dan kepastian, hal ini rupanya selaras dengan prinsip manajmen mutu menurut Kotler.MI Darul Huda menerapkan total quality management dengan menempatkan pelanggan sebagai prioritas melalui pelayanan yang rpima, sehingga baik pendidik, peserta didik, dan karyawan berada pada loyalitas yang tinggi.Tingkat kepuasan pendidik dan tenaga kependidikan yang tinggi di MI Darul Huda ternyata mampu meningkatkan kualitas layanan Pendidikan kepada para peserta didik.

Selanjutnya, kualitas pelayanan peserta didik yang tinggi ternyata mampu menghantarkan pada peningkatan kualitas motivasi belajar, sehingga hal ini mampu mendongkrak prestasi peserta didik, baik akademik maupun non akademik.Pada ahirnya, kualitas prestasi akademik dan non akademik peserta didik mampu meningkatkan kepuasan orangtua wali, sehingga terbentuk sinergi antara Lembaga Pendidikan dengan orangtua wali secara maksimal. Segala aspek mutu tersebut selanjutnya mampu menghantarkan pada tercapainya visi dan misi MI Darul Huda secar maksimal. 


\section{DAFTAR PUSTAKA}

Asmuni, "KonsepMutudanTotalQualityManagementdalamDuniaPendidikan," $T$ a'dibXVIII no.1 (Juni, 2013).

Darmadji, "Implementasi Total Quality Management sebagai Upaya Peningkatan Mutu Pendidikan di MAN Model Yogyakarta," ElTarbawy Jurnal Pendidikan Islam 1 No. 2 November, 2008.

Edward Sallis, Total Quality Mangement in Education. (Yogyakarta: IRCiSoD, 2015).

Marno dan Triyo Supriyatno, Manajemen dan Kepemimpinan Islam (Bandung: Refika Aditama, 2008).

Muchlas Samani, dkk., Manajemen Sekolah (Yogyakarta: Adicita Karya Nusa, 2009).

Parasuraman A, Leonard Berry, dan Valarie A. Zeithaml, "The Nature and Determinant of Custumer Expectations of Service," Journal of the Academy of Marketing Science 1 no. 21 (April, 1993).

Tenner dan Detoro, Total Quality Management Three Steps to Continous Improvement,(New York: Addison Weley Publishing Company, 1992).

Uhar Suharsaputra, Manajemen Pendidikan Perguruan Tinggi (Bandung: Refika Aditama, 2015).

Zeithaml dan Bitner, Service Marketing (New Jersey: Graw Hill, 2000). 